\title{
SECURITIES REGULATION: EXEMPTION OF SHORT TERM PROFITS FROM RECOVERY UNDER SECTION I6(b)
}

SEcrion I6(b) of the Securities Exchange Act of I 934 allows a corporation to recover any profits made within a six month period by an "insider" trading in its securities, "unless such security was acquired in good faith in connection with a debt previously contracted." $\mathrm{Al}$ though section $16(\mathrm{~b})$ has been repeatedly litigated, ${ }^{3}$ the statutory exemption, unmentioned in the legislative history, ${ }^{4}$ had not undergone intensive judicial examination until the recent case of Rheem Mfg. Co. v. Rheem. ${ }^{5}$

Defendant Rheem retired as chief executive officer of the company in 1958. Pursuant to the company's retirement plan which allowed an election between insurance, company stock, annuities, or cash, he chose to receive benefits in the form of stock. For accounting pur-

\footnotetext{
"The term "insider" is defined by the statute to include "every person who is directly or indirectly the beneficial owner of more than so per centum of any class of any equity security (other than an exempted security) which is registered on a national securities exchange, or who is a director or an officer of the issuer of such security ...." 48 Stat. 896 (1934), I5 U.S.C. $\$ 78 p$ (a) (1958).

For a general discussion of judicial interpretation of this statutory definition, see 2 Loss, Securities Regulation 1091-108 (2d ed. 196I), and sources cited therein.

9 "For the purpose of preventing the unfair use of information which may have been obtained by such beneficial owner, director, or officer by reason of his relationship to the issuer, any profit realized by him from any purchase and sale, or any sale and purchase, of any equity security of such issuer (other than an exempted security) within any period of less than six months, unless such security was acquired in good faith in connection with a debt previously contracted, shall inure to and be recoverable by the issuer, irrespective of any intention on the part of such beneficial owner, director, or officer in entering into such transaction of holding the security purchased or of not repurchasing the security sold for a period exceeding six months. Suit to recover such profit may be instituted at law or in equity in any court of competent jurisdiction by the issuer, or by the owner of any security of the issuer in the name and in behalf of the issuer if the issuer shall fail or refuse to bring such suit within sixty days after request or shall fail diligently to prosecute the same thereafter; ..." 48 Stat. 896 (1934), 15 U.S.C. $\$ 78 \mathrm{p}$ (b) (1958).

${ }^{a}$ For a general discussion of the prohlems litigated, see Cole, Insiders Liabilities Under the Securities Exchange Act of 3934,12 Sw. L.J. 147 (1958); Cook \& Feldman, Insider Trading Under The Securities Exchange Act (pts. I-2), 66 HARv. L. REv. 385,612 (1953) ; Rubin \& Feldman, Statutory Inhibitions Upon Unfair Use of Corporate Information by Insiders, 95 U. PA. L. REv. 468 (1947).

"The legislative history of the act is found in H.R. Rep. No. ${ }^{138} 83,73$ d Cong., ad Sess. 13-14, 24-25 (1934); S. Rep. No. 792, 73d Cong., 2d Sess. 9, 20-21 (1934); H.R. Rep. No. I838, 73d Cong., 2d Sess. I6-17, 35-36 (1934).

${ }_{295}$ F.2d 473 (9th Cir. 196r).
} 
poses the company issued Rheem a check for his final balance in the plan, and he in turn gave his personal check for the number of shares closest in value to this interest. He then assigned these shares to a bank under a general pledge of all his assets made in connection with a prior indebtedness. Later, the pledgee began selling the collateral. At the request of a stockholder, ${ }^{6}$ the corporation brought suit to recover the profit realized. The trial court gave judgment for the defendant, basing its decision on the finding, inter alia, that the stock was acquired in good faith in connection with a debt previously contracted. ${ }^{7}$ On appeal, the Court of Appeals for the Ninth Circuit affirmed.

Dealing separately with each element of the exemption, the court first discussed the requirement of "a debt previously contracted." The few earlier cases tended to give this phrase a rather narrow construction. For example, acquisitions of stock through the exercise of a conversion privilege ${ }^{8}$ or a non-assignable option to buy $^{9}$ have been

- This same shareholder later intervened and appealed to the Court of Appeals after the Board of Directors of the plaintiff corporation declined to do so. See 295 F.2d at 474 .

The trial court made two other relevant findings of fact: (1) the defendant acquired his stock six months prior to the initial sale by the bank; (2) the defendant did not sell any stock of the plaintiff corporation. Id. at 475. Although either finding would have been sufficient to exempt Rheem from the operation of the statute, the Ninth Circuit preferred to rest its decision solely upon the statutory exemption.

${ }^{B}$ Park \& Tilford, Inc. v. Schulte, 160 F.2d 984 (2d Cir.), cert. denied, 332 U.S. 761 (1947); Kogan v. Schulte, 61 F. Supp. 604 (S.D.N.Y. 1945). In these cases, which arose from a single transaction, the defendant owned preferred stock which was convertible to common at his option. He exercised this option, received common stock, and subsequently sold it within six months. When the company brought suit under $\S I 6(b)$, defendant unsuccessfully urged that his acquisition fell within the exemption. The court, pointing out that the ownership of stock creates only an equitable interest, held that "the exception is clearly inapplicable to anything except transactions in connection with actual debts." I60 F.2d at 987 .

This problem is to be distinguished from that of whether such conversion is a "purchase" under 16(b). See 2 Loss, SEcuRities Regulation 1066-72 (2d ed. 1961 ).

'Blau v. Ogsbury, CCH FED. SEC. L. REP. I 90,635 (S.D.N.Y. 1953), aff'd, 2 10 F.2d 426 (2d Cir. 1954) (no consideration of the exemption on appeal). Defendant's employment contract gave him an option to buy ro,000 shares of stock. The contract provided that the date of mailing an acceptance would be the date of title transfer, the defendant to become a debtor for the purchase price at that time. The option was exercised on December 29, 1945, but the stock was not delivered and paid for until December 13, 1948. Since the defendant had sold company stock within the previous six months, he was sued under $\S 16(\mathrm{~b})$ for his profits. His argument that the stock came within the exemption was rejected: "The promise by the corporation to deliver the stock upon payment did not constitute Ogsbury a creditor, as defendant contends. 
held not covered by the exemption. Even where stock was acquired through warrants given in satisfaction of a contractual obligation, the required "debt previously contracted" was held to be lacking. ${ }^{10}$ In the instant case, however, the Ninth Circuit found the necessary debt, which it defined as "an obligation to pay a fixed sum certainly and at all events, existing prior to and apart from the settlement of the obligation by the transfer of stock."11

This definition is apparently consistent with those found in earlier decisions. Thus the requirement that the debt exist apart from the transfer of stock would eliminate transactions involving the exercise of warrants and conversion rights. ${ }^{12}$ Furthermore, any recurring debt to be paid in stock would fail to come within the exemption because the debt not only is inseparable from the transfer of stock, but also does not represent a fixed, definite sum. ${ }^{13}$

The court's definition, although consistent with the previous cases, does raise other problems. First, it would encompass the obligations incurred under many pension plans. By rule $16 \mathrm{~b}-3,{ }^{14}$ the Securities and Exchange Commission previously had exempted from section I6(b) stock acquired under pension and incentive plans meeting certain conditions designed to protect the stockholders of the issuing corpora-

The exception in the statute is limited to securities acquired in payment of an actual debt." Blau v. Ogsbury, supra I 90,635 , at 91,929 .

${ }^{10}$ Truncale v. Blumberg, 80 F. Supp. ${ }^{8} 7$ (S.D.N.Y. 1948), aff'd per curiam sub nom. Truncale v. Scully, 182 F.2d 102 I (2d Cir. 1950). Defendant, the chief financial officer of a corporation, received annual stock warrants as part of his compensation. The exemption was held not to apply, although it is not clear from the opinion whether the court based its decision on the ground that the recurring nature of the contractual obligation precluded good faith acquisition of the stock, or on the ground that there was no debt within the meaning of the statutory exemption.

The exemption has been held applicable in only one case. Smolowe v. Delendo Corp., I 16 F.2d 23 I (2d Cir.), cert. denied, 320 U.S. 751 (I943). One defendant paid a debt owing to a second defendant in company stock. The court held that the shares received by the creditor fell within the exemption, but that the purchase of shares by the debtor to pay the debt did not.

11295 F.2d at 476 .

${ }^{29}$ Park \& Tilford, Inc. v. Schulte, r6o F.2d 984 (2d Cir.), cert. denied, 332 U.S. 761 ( 1947$)$.

${ }^{18}$ An example of such a debt would be the compensatory stock warrants involved in Truncale v. Blumberg, 80 F. Supp. 387 (S.D.N.Y. 1948), aff'd per curiam sub nom. Truncale v. Scully, 182 F.2d 1021 (2d Cir. 1950). The warrants in this case were for a certain number of shares, rather than for a definite sum of money. Thus the monetary value of the debt could not be ascertained until the stock was acquired.

14 17 C.F.R. $\$ 240.16 b-3$ (Supp. I 962 ). 
tion. ${ }^{15}$ If the Ninth Circuit's construction of the statutory exemption is broader than the SEC's rule, the safeguards of the latter would seem largely vitiated. The good faith requirement of the statutory exemption will, however, serve as a check on these transactions. Moreover, the courts can continue to give weight to the judgment of the Commission as expressed in rule $16 \mathrm{~b}-3$, requiring something akin to the safeguards of that rule to establish good faith in future transactions of this type.

The Ninth Circuit's definition, moreover, is susceptible of varying interpretations. Indeed, under this definition the pension plan involved in the instant case would seem to be a debt connected with a transfer of stock and hence not within the exemption were it not for the option provision allowing payment in other forms. Yet that option permitted Rheem to decide whether he would take payment in stock or other valuables, a determination which would naturally be influenced by inside information. Thus the holding in this case would seem to allow "insider" speculation, a direct subversion of the statutory purpose. However, the court emphasized that the definition was complementary to the requirement of good faith, ${ }^{16}$ and that at no time did the defendant use any inside information or act in bad faith. ${ }^{17}$ Thus, once again, the requirement of good faith seemed to be determinative.

The court's constant emphasis on the matter of good faith clearly showed it to be the "controlling question."18 Turning specifically to this question, the court said that the party seeking to invoke the exemption has the burden of bringing himself clearly within it. ${ }^{19}$ The

${ }^{25}$ Rule $16 \mathrm{~b}-3$ sets forth three conditions which must be met for a plan to qualify for the exemption: ( 1 ) the plan must be approved by a majority of stockholders of the corporation; (2) the benefits dispensed must be controlled by disinterested committees; (3) the dollar amount or number of shares received must be limited, either on an annual or aggregate basis.

10295 F.2d at 476.

17 "The district court explicitly found that '[a]t no time did the defendant use or attempt to use any information which may have been gained by him by reason of his relationship to the plaintiff', and that '[a]t all times defendant . . . acted in good faith .with respect to the matters referred to in the complaint ...'" 295 F.2d at 477.

${ }^{18} 295$ F.2d at 476.

The court summarily dealt with the question of whether the stock was acquired "in connection with" the debt. 'The intervening shareholder argued that Rheem's issuance of a personal check constituted an independent purchase of stock. The court rejected such a narrow approach and looked rather to the substance of the whole transaction. The various steps taken were required by the company's accounting practices and thus should not alter the essential nature of the exchange. Ibid.

${ }^{10}$ Id. at 477 . 
intervening stockholder, supported by the only available authority, argued that Rheem could sustain this burden only by showing that his acquisition of stock was completely involuntary. ${ }^{20}$ The court stated, however, that Congress intended here to replace the objective standard used elsewhere in the Securities Exchange Act ${ }^{21}$ with a standard of subjective intent. Therefore, volition in the acquisition was but one factor to be considered in determining good faith.

Although the court did not explicitly mention other factors relevant to good faith, some were implicit in its examination of the facts. One such factor was the purpose for which the stock was acquired. The court stressed the fact that Rheem chose stock in order to build up his estate, a purpose not frowned upon by the statute. ${ }^{22}$ A related factor was whether or not the defendant intended to sell within six months. The court indicated that even an involuntary recipient of stock who had such intent would come under the operation of section $16(\mathrm{~b}) .^{23}$ The fact that the sale took place pursuant to a decision of the pledgee bank, not of the defendant, was also considered. Although the statutory exemption literally requires good faith only in the acquisition of securities, the nature of the subsequent sale would seem relevant as evidence that the acquisition was in good faith. ${ }^{24}$ In the instant case, however, the court was not required to consider the effect of a voluntary sale on this question. The primary factor thus seemed to be the possibility, under a given set of facts, that the transaction might afford "unfair" use of inside information. Indeed, the court indicated "that there may ... be cases so shot through with the possibilities of unfair speculation that a party cannot overcome the inference of bad faith. ${ }^{325}$

${ }^{20}$ One law review article said that "so long as the requirement of 'good faith' is satisfied-presumably it would not be where the substitution of securities in satisfaction of the claim was at the choice of the creditor-the opportunities for abuse of inside information would not be present." Cook \& Feldman, supra note 3, at 633. Another article contended that "if it was not clearly necessary to take stock in payment [of the debt], then we believe the courts will hold it not within the exemption contained in $\S$ 16(b)." Rubin \& Feldman, supra note 3 , at 487 . This position is also supported by dictum in Perlman v. Timberlake, 172 F. Supp. 246, 255 (S.D.N.Y. 1959).

${ }^{21}$ No actual use of inside information or intent to sell out in less than six months is required to give rise to liability under the general provisions of the act. All that is required is a purchase and sale within six months by an "insider." 295 F.2d at 475 .

${ }_{22} 295$ F.2d at 477.

${ }^{23}$ The court felt that "in a given case the fact of involuntariness might not be conclusive, for the creditor might still, upon acquisition of the stock, have advance information and an intention to get out on a short swing." Ibid.

${ }^{24}$ Ibid.

${ }^{25} \mathrm{Ibid}$. 
The detailed definition of "debt previously contracted" offered by the Ninth Circuit in the Rheem case would seem to vitiate somewhat the effectiveness of rule $16 \mathrm{~b}-3$, and to create interpretative problems. Thus the most significant contribution of the decision was its exhaustive consideration of the "good faith" requirement of the exemption from Section I6(b) of the Securities Exchange Act. Of course, the question of good faith remains, as before, a matter for ad hoc decision. The basic purpose of the statute is to prevent the use of inside information to make a profit in company stock. As was done in the instant case, the determination of good faith should be based on a critical examination of all elements of the transaction in an effort to insure that actions taken in derogation of this purpose are not successful. 